\title{
Determination of serum hepatitis B virus DNA in HBV endemic region: Clinical significance and correlation with serological markers, ALT and AST
}

\author{
HBV endemik bölgede serum HBV DNA düzeylerinin klinik önemi ve \\ serolojik ișaretler, ALT, AST ile ilișkisi
}

Tuba MUDERRIS ${ }^{1}, \quad$ Osman Sezer CIRIT², $\quad$ Tulin YAZICl ${ }^{3}$,

\section{ABSTRACT}

Objective: The aim of this study is to investigate, demographics and the relationship between serologic markers, liver enzymes and HBV DNA levels from the patients whose samples were sent to microbiology laboratory for HBV DNA polymerase chain reaction $(P C R)$ test, in one of the greatest cities of Southeast Anatolia, where HBV infection is extremely common.

Method: Between October 2009 and October 2010, blood samples of 1662 patients were sent to our laboratory for HBV DNA PCR testing as part of a routine examination for viral hepatitis in Şanlıurfa Training and Research Hospital in Turkey. Hepatitis markers (HBsAg, HBeAg, anti-HBs, anti-HBc IgM) and liver function enzymes (ALT, AST) are tested simultaneously in these samples. $\mathrm{HBsAg}, \mathrm{HBeAg}$, anti-HBs and anti$\mathrm{HBC}$ IgM levels were assessed with chemiluminescent microparticle immunoassay method (Architect-i2000 SR, Abbott, Ireland). ALT and AST levels were measured with commercial kits in Roche Modular-P and RocheIntegra autoanalysator (Roche Diagnostics Mannheim, Germany). HBV DNA PCR: Isolation of HBV DNA from serum samples was done with M24sp automated extraction device (Abbott, USA). Purified DNA was amplified with Real-Time PCR method with the help of Abbott-m2000 sample preparation system (Abbott, USA).

\section{ÖZET}

Amaç: Bu çalıșmanın amacl, HBV infeksiyonunun son derece yaygın olduğu Güneydoğu bölgesindeki büyük șehirlerden birinde HBV DNA polimeraz zincir reaksiyonu (PCR) testi için mikrobiyoloji laboratuvarına gönderilen hasta örneklerinde, demografik özellikler ve serolojik belirteçler, karaciğer enzimleri ve HBV DNA seviyeleri arasındaki ilișkileri incelemektir.

Yöntem: Ekim 2009-Ekim 2010 tarihleri arasında Şanlıurfa Eğitim ve Araștırma Hastanesinde viral hepatitin rutin testlerinin bir parçası olan HBV DNA PCR testi için 1662 hastanın kan örneği laboratuvarımıza gönderildi. Bu örneklerde eș zamanlı olarak hepatit belirteçleri (HBsAg, HBeAg, anti-HBs ve anti-HBc IgM) ve karaciğer fonksiyon enzimleri (ALT, AST) çalıșıldı.HBsAg, HBeAg, anti-HBs ve anti$\mathrm{HBC}$ IgM seviyeleri kemiluminesan mikropartikül immunoassay yöntemi ile (Architect i2000 SR, Abbott, Ireland) çalışıldd. ALT ve AST seviyeleri Roche Modular $P$ ve Roche Integra otoanalizörde (Roche Diagnostics Mannheim, Germany) ticari kitler ile ölçüldü. HBV DNA PCR: Serum örneklerinde HBV DNA'nın izolasyonu M24sp otomatize ekstraksiyon cihazı (Abbott, USA) ile yapıldı. Saflaștırıııș DNA Abbott m2000 sample preparation system (Abbott, USA) yardımı ile ve RealTime PCR yöntemi ile DNA amplifikasyonu yapıldı.

\footnotetext{
'Ankara Atatürk Training And Research Hospital Department of Medical Microbiology, Ankara, Turkey

${ }^{2}$ Şanlıurfa Training And Research Hospital Department of Medical Microbiology, Şanlıurfa, Turkey
}

${ }^{3}$ Şanlıurfa Traning And Research Hospital Department of Medical Biochemistry, Şanlıurfa, Turkey

İletişim/ Corresponding Author: Tuba MÜDERRiS

Ankara Atatürk Training and Research Hospital Department of Medical Microbiology, Ankara, Turkey

Tel : +905055025143_ E-posta/E-mail : tubamuderris@yahoo.com

Geliş Tarihi / Received : 06.08.2015 Kabul Tarihi / Accepted : 25.02.2016

DOI ID : 10.5505/TurkHijyen.2016.66563

Müderris T, Cirit OS, Yazıcı T. Determination of serum hepatitis B virus DNA in HBV endemic region: Clinical significance and correlation with serological markers, ALT and AST Turk Hij Den Biyol Derg, 2016; 73(3): 211-220 
Results: The mean age was 33.7 (Min-Max: 0-89) years old and the majority of the patients were male (Male/Female: 1103/559) in the study. HBsAg was positive in $96.2 \%$ of the patients and the median ALT level of these patients were $94 \mathrm{u} / \mathrm{l}$ (Min-Max: 4-2390 $\mathrm{u} / \mathrm{l}$ ), while median AST level was $74 \mathrm{u} / \mathrm{l}$ (Min-Max: 7-2505 u/l). HBV DNA was positive in $94.6 \%$ of HBsAg positive patients and the median HBV DNA level was 3.9x104 copies/ml (Min-Max: 35-3.4x109 copies/ml). $\mathrm{HBeAg}$ was positive in $17.1 \%$ of $\mathrm{HBsAg}$ positive patients. Median levels of ALT and AST in HBsAg negative patients (3.8\%) were $32 \mathrm{u} / \mathrm{l}$ (Min-Max: 7-497 $\mathrm{u} / \mathrm{l}$ ) and $33 \mathrm{u} / \mathrm{l}$ (MinMax: $13-280 \mathrm{u} / \mathrm{l}$ ) respectively. HBV DNA was positive in only $7.9 \%$ of the patients with median HBV DNA level of 155 copies/ml (Min-Max: 34-624 copies/ml). HBeAg was found negative in $71.4 \%$ of patients with negative $\mathrm{HBsAg}$ and positive HBV DNA. In 26 of 1662 patients (1.6\%), both $\mathrm{HBsAg}$ and Anti-HBs were negative (N/N). Only two of the N/N patients $(7.7 \%)$ were found anti-HBc positive. Mean ALT and AST levels of two anti-HBc positive patients were $29.5 \mathrm{u} / \mathrm{l}$ and $30.5 \mathrm{u} / \mathrm{l}$, respectively. HBV DNA was negative in one of these patients, and the other was found positive with a level of $3 \times 10^{2}$ copies $/ \mathrm{ml}$.

Conclusion: To acquire more reliable results on the diagnosis and follow-up of the treatment of Hepatitis $B$, quantitative HBV DNA tests should be used in together with more frequently used serologic and biochemical methods.

Key Words: HBV DNA, HBsAg, HBeAg, Anti-HBs, Anti-HBc, ALT, AST
Bulgular: Çalıșmamızda ortalama yaș 33,7 (Min-Maks: 0-89) ve örneklerin çoğunluğu erkek cinsiyettedir (Erkek/Kadın: 1103/559). Hastaların \%96.2'sinin HBsAg'si pozitifti ve bu hastaların ortanca ALT seviyesi $94 \mathrm{u} / \mathrm{l}$ (Min-Maks: 4-2390 u/l) iken, ortanca AST seviyesi $74 \mathrm{u} / \mathrm{l}$ (Min-Maks: 7-2505 u/l)'dir. HBsAg pozitif hastaların \%94.6'sında HBV DNA pozitif ve ortanca HBV DNA düzeyi 3.9×104 kopya/ml (Min-Maks: 35-3.4x109 kopya/ml)'dir. HBsAg pozitif hastaların \%17.1'inde HBeAg pozitif idi. HBsAg negatif hastaların (\%3.8) ortalanca ALT ve AST düzeyleri sirasıyla $32 \mathrm{u} / \mathrm{l}$ (Min-Maks: 7-497 u/l) ve $33 \mathrm{u} / \mathrm{l}$ (MinMaks: 13-280 u/l)'dir. HBV DNA hastaların sadece \%7.9'unda pozitifti ve ortanca HBV DNA seviyesi 155 kopya/ml (Min-Maks: 34-624 kopya/ml) idi. HBsAg negatif ve HBV DNA pozitif hastaların \%71.4'ünde HBeAg negatif bulundu. 1662 hastanın 26 (\%1.6)'sında HBsAg ve Anti-HBs' nin her ikisi de negatif (N/N) idi. Bu N/N hastalarının sadece ikisi (\%7.7) anti-HBc pozitif bulundu. İki anti-HBc pozitif hastanın ortalama ALT ve AST seviyeleri sirasiyla $29.5 \mathrm{u} / \mathrm{l}$ ve $30.5 \mathrm{u} / \mathrm{l} \mathrm{idi}$. Bu hastaların birinin HBV DNA'sı negatif idi ve diğeri $3 \times 10^{2} \mathrm{kopya} / \mathrm{ml}$ ile pozitif bulundu.

Sonuç: Hepatit B infeksiyonlarının tanısında ve tedavisinin takibinde daha güvenilir sonuçlar elde edebilmek için daha sık kullanılan serolojik ve biyokimyasal testler ile birlikte kantitatif HBV DNA testleri kullanılmalıdır.

Anahtar Kelimeler: HBV DNA, HBsAg, HBeAg, Anti$\mathrm{HBs}$, Anti-HBc, ALT, AST

\section{INTRODUCTION}

Hepatitis B virus (HBV) is a noncytopathic, hepatotropic virus of the Hepadnaviridae family that causes variable degrees of liver disease in humans. HBV carriers are at risk of developing life threatening cirrhosis (30\%) and later on hepatic carcinoma (6$17.5 \%)$. Despite the availability of a prophylactic vaccine, $\mathrm{HBV}$ is estimated to infect around 400 million people worldwide and it is endemic in Asia and Africa (1). It will increase by nearly 50 million people a year with nearly two million deaths related to acute and chronic complications of HBV. World Health Organization reported that the virus causes hepatic carcinoma over 300.000 patients annually. HBV carriers are the most important factor in the 
dissemination of HBV infection. Turkey is among the moderate endemic regions with a carrier rate of 3.912.5\%. Various studies revealed even higher rates in Eastern and Southeastern regions of Turkey with remarkable rates of childhood transmission (2).

Viral antigens and antibodies that emerge against them, are commonly used in diagnosis and for determination of the prognosis of HBV infection (3). Serological tests can provide accurate information about acute, chronic or previous HBV infection. Routine serological tests that are used in the diagnosis of HBV are; Hepatitis B surface antigen ( $\mathrm{HBsAg}$ ), hepatitis $B$ surface antibody (anti-HBs), hepatitis $B$ core antibody (anti-HBc), hepatitis $B$ envelope antigen ( $\mathrm{HBeAg}$ ) and $\mathrm{HBe}$ antibody (anti-HBe) (4).

HBsAg is the most important marker for the diagnosis of acute and chronic hepatitis $B$ virus and indicates potential infectiousness. It is one of the first serum markers to appear during the course of HBV infection. It is also useful as a follow-up marker, since declining concentrations are observed in resolving hepatitis B. HBsAg usually becomes undetectable after 4-6 months. If HBsAg persists for more than 6 months, the infected individual is considered as a chronic HBV carrier. Anti-HBs antibodies become detectable late in convalescence. Hepatitis B e antigen ( $\mathrm{HBeAg}$ ) protein appears shortly after the appearance of HBsAg and disappears within several weeks as acute hepatitis resolves. Its presence in the serum correlates with presence of viral replication in the liver. Antibody to hepatitis B core antigen (Anti$\mathrm{HBC}$ ) IgM is detectable at the outset of clinical disease and as the infection evolves, it gradually decline and become undetectable within six months. Anti-HBC IgG predominates and remains for a long time at detectable levels (5).

Lately, detection of HBV DNA in the serum and viral quantitation have an increasingly important role in diagnosis of the disease, designing the treatment and determination of the efficacy of antiviral therapy. (6). The correlation between the $\mathrm{HBsAg}$ and the number of HBV particles is a key point, since this marker is used with a wide range of HBV particles in blood, depending on the infections state (7). Clinical liver function biomarkers, used for the diagnosis of liver damage and/or evaluation of treatment includes alanine aminotransferase (ALT) and aspartate aminotransferase (AST) (8). Due to serious clinical problems that the infection may cause and the potential for obstinacy, accurate use and interpretation of laboratory tests have a crucial role in the diagnosis of the infection (4).

In this study, patient demographics and the relationship between serologic markers, liver enzymes and HBV DNA levels are investigated in patient samples that were sent to our microbiology laboratory for HBV DNA polymerase chain reaction (PCR) test, in one of the developed cities of Southeastern region of Turkey, where HBV infection is extremely common.

\section{MATERIAL and METHOD}

This study was carried out between 01 October 2009 and 31 October 2010. Blood samples of 1662 patients were sent to our laboratory for HBV DNA PCR testing as part of a routine examination for viral hepatitis in Şanlıurfa Training and Research Hospital, Turkey. Hepatitis markers ( $\mathrm{HBsAg}$, $\mathrm{HBeAg}$, anti-HBs and anti-HBc $\lg M$ ) and liver function enzymes (ALT, AST) are tested simultaneously in these samples.

$\mathrm{HBsAg}, \mathrm{HBeAg}$, anti-HBs and anti-HBc IgM levels were assessed with chemiluminescent microparticle immunoassay method with Architect i2000 SR (Abbott, Ireland) system.

ALT and AST levels were measured with commercial kits in Roche Modular P and Roche Integra autoanalysator (Roche Diagnostics Mannheim, Germany). The normal concentrations in the blood were between 5 to $41 \mathrm{U} / \mathrm{L}$ for AST and 5-38 u/l for ALT.

Isolation of HBV DNA from serum samples was done with M24sp automated extraction device (Abbott, 
USA). Purified DNA was amplified with Real-Time PCR method using Abbott m2000 sample preparation system (Abbott, USA). The target sequence for the Abbott RealTime HBV assay is in the surface gene in the HBV genome. This region is specific for HBV and is highly conserved. The primers are designed to hybridize to this region with the fewest possible mismatches among HBV genotypes A through $\mathrm{H}$. The lower limit of this commercial test was 34.1 copy/ $\mathrm{ml}$ where upper limit was $3.41 \times 10^{9} \mathrm{copy} / \mathrm{ml}$. Three controls (negative control, low positive control and high positive control) were included in to the study for determination of contamination and evaluation of the results.

\section{RESULTS}

One thousand one hundred and three of the subjects were male and 559 were female, with a mean age of 33.7 years (Min-Max: 0-89). Patient demographics and test results according to age groups are summarized in Table 1.
Median ALT level of HBsAg positive patients, which consisted $96.2 \%$ of all patients, was $94 \mathrm{u} / \mathrm{l}$ (Min-Max: 4-2390 u/l)., while median AST level was $74 \mathrm{u} / \mathrm{l}$ (Min-Max: 7-2505 u/l). Of these HBsAg positive patients, HBV DNA was positive in $94.6 \%$ and median HBV DNA level was $3.9 \times 104$ copies $/ \mathrm{ml}$ (Min-Max: 35-3.4x109 copies/ml). Median ALT/AST levels of patients with HBV DNA levels $\leq 10^{3}$ copies/ $\mathrm{ml}, 10^{3}-10^{5}$ copies $/ \mathrm{ml}$ and $\geq 10^{5}$ copies $/ \mathrm{ml}$ were 50 (Min-Max: 6-1158 u/l)/39 (Min-Max: 9-1636 u/l) u/l, 54 (Min-Max: 4-2053 U/L)/43 (Min-Max: 7-2505 U/L) U/L and 86 (Min-Max: 9-2390 U/L)/68 (Min-Max: 151967 U/L) U/L respectively. Median ALT/AST levels of patients with negative HBV DNA were 35(Min-Max: 10-156 U/L)/32 (Min-Max: 13-95 U/L) U/L. HBeAg was positive in $17.1 \%$ of $\mathrm{HBsAg}$ positive patients. $\mathrm{HBeAg}$ positivity rates of patients with HBV DNA $\leq 10^{3}$ copies/ $\mathrm{ml}, 10^{3}-10^{5}$ copies $/ \mathrm{ml}, \geq 10^{5}$ copies $/ \mathrm{ml}$ were $18.4 \%$, $15.4 \%$ and $65.1 \%$, respectively. HBeAg was positive only in $1.1 \%$ of $\mathrm{HBsAg}$ positive patients with negative HBV DNA. HBeAg, HBV DNA and ALT/AST levels of

Table 1. Demographic characteristics and serological test results of 1662 subjects, Șanlıurfa, October 2009-2010

\begin{tabular}{|c|c|c|c|c|c|c|c|c|}
\hline & \multirow{2}{*}{ NO. } & \multirow{2}{*}{$M / F$} & \multicolumn{2}{|c|}{ HBsAg } & \multicolumn{4}{|c|}{ HBsAg/Anti-HBs } \\
\hline & & & $\mathbf{P}$ & $N$ & $P / P$ & $\mathrm{P} / \mathrm{N}$ & N/P & $\mathrm{N} / \mathrm{N}$ \\
\hline \multicolumn{9}{|l|}{ Sex } \\
\hline Male & $559(33.6 \%)$ & & $538(32.4 \%)$ & $21(1.3 \%)$ & $89(5.4 \%)$ & $449(27.0 \%)$ & $10(0.6 \%)$ & $11(0.7 \%)$ \\
\hline Female & $1103(66.4 \%)$ & & $1061(63.8 \%)$ & $42(2.5 \%)$ & $158(9.5 \%)$ & 903 (54.3\%) & $27(1.6 \%)$ & $15(0.9 \%)$ \\
\hline \multicolumn{9}{|l|}{ Age (years) } \\
\hline $0-14$ & $110(6.6 \%)$ & $63 / 47$ & $108(96.2 \%)$ & $2(0.1 \%)$ & $23(1.4 \%)$ & $85(5.1 \%)$ & $2(0.1 \%)$ & 0 \\
\hline $15-40$ & $1046(62.9 \%)$ & $714 / 332$ & $1015(61.1 \%)$ & $31(1.9 \%)$ & $126(7.6 \%)$ & 889 (53.5\%) & $15(0.9 \%)$ & $16(1.0 \%)$ \\
\hline $41-60$ & $444(26.7 \%)$ & $294 / 150$ & $419(25.2 \%)$ & $25(1.5 \%)$ & $89(5.4 \%)$ & $329(19.8 \%)$ & $16(1.0 \%)$ & $9(0.5 \%)$ \\
\hline$\geq 61$ & $62(3.7 \%)$ & $32 / 30$ & $57(3.4 \%)$ & $5(0.3 \%)$ & $9(0.5 \%)$ & $48(2.9 \%)$ & $4(0.2 \%)$ & $1(0.1 \%)$ \\
\hline Total & 1662 & $1103 / 559$ & $1599(96.2 \%)$ & $63(3.8 \%)$ & 247 (14.9\%) & 1352 (81.3\%) & $37(2.2 \%)$ & $26(1.6 \%)$ \\
\hline
\end{tabular}

M: male, F: female, P: positive, N: negative 
HBsAg positive patients are summarized in Table 2.

Median ALT level of HBsAg negative patients (3.8\%) was $32 \mathrm{U} / \mathrm{L}$ (Min-Max: 7-497 U/L) and median AST level was $33 \mathrm{U} / \mathrm{L}$ (Min-Max: 13-280 U/L). HBV DNA was negative in $92.1 \%$ of these patients where it was positive in $7.9 \%$, with a median HBV DNA level of 155 copies/ml (Min-Max: 34-624 copies/ $\mathrm{ml})$. HBeAg was negative in $71.4 \%$ of patients with negative HBsAg and positive HBV DNA. Anti-HBC and anti-HBs was positive in these patients $(0.3 \%$ of total)

In 26 of 1662 patients (1.6\%), both HBsAg and anti-HBs were negative $(\mathrm{N}, \mathrm{N})$. Among these $\mathrm{N} / \mathrm{N}$ individuals, 24 (92.3\%) were anti-HBc negative and $2(7.7 \%)$ were anti-HBc positive. The incidence of being $\mathrm{N} / \mathrm{N}$ was higher in women $(2 \%)$ than in men $(1.4 \%)$. The prevalence of being $N / N$ was highest in the group aged 41-60 years $(2.0 \%)$, where it was $1.6 \%$ in the age group over 61 years, and lowest (1.4\%) in the age group under 40 years (Table 3 ). The prevalence did not decrease according to age. Mean ALT level of the two anti-HBc positive patients was $29.5 \mathrm{U} / \mathrm{L}$, and mean AST level was $30.5 \mathrm{U} / \mathrm{L}$. HBV DNA was negative in one of these patients, and the other had a HBV DNA level of $3 \times 10^{2}$ copies $/ \mathrm{ml}$.

\section{DISCUSSION}

HBV viral load measuring is a very important tool for monitoring HBV infected patients. The most direct and reliable measurement of viral replication is HBV DNA quantification, which can replace other indirect methods to assess the efficacy of antiviral therapy used to treat HBV infected patients, such as serologic markers or measurement of liver enzyme functions. Monitoring the HBV viral load can predict the evolution to cirrhosis and hepatocellular carcinoma (9), as well as a rapid and sustained response to treatment as a predictive factor for a favorable treatment outcome. It can also provide an early detection of treatment failure that may be related to poor adherence to therapy or selection of a resistant virus. The likelihood of resistance to nucleotide analogues is very low when HBV DNA level is undetectable during therapy and increases proportionally to the HBV DNA level (10).

Turkey is an intermediate endemic area (2-8\%) for HBV infection. However, the east and southeast region of Turkey is known as an endemic area for HBV infection in Turkey (11) and this study is performed in one of the largest cities of Southeastern Anatolia. In our study, mean age (33.7) of HBsAg positive patients

Table 2. The relationship between HBV DNA, HBeAg positivity and ALT/AST levels in HBsAg positive patients, Șanliurfa, October 2009-2010

\begin{tabular}{|c|c|c|c|c|c|c|c|}
\hline & & & \multicolumn{4}{|c|}{ ALT/AST } & \multirow{2}{*}{ Total } \\
\hline & & & N/N & N/H & $\mathrm{H} / \mathrm{N}$ & $\mathrm{H} / \mathrm{H}$ & \\
\hline \multirow[t]{5}{*}{$\begin{array}{l}\text { HBsAg + } \\
(96.2 \%)\end{array}$} & \multirow{2}{*}{$\begin{array}{c}\mathrm{HBeAg}+ \\
(17.1 \%)\end{array}$} & HBV DNA + & 69 & 34 & 45 & 122 & 270 \\
\hline & & HBV DNA - & 3 & 0 & 0 & 0 & 3 \\
\hline & \multirow{2}{*}{$\begin{array}{c}\mathrm{HBeAg}- \\
(83.0 \%)\end{array}$} & HBV DNA + & 612 & 258 & 266 & 107 & 1243 \\
\hline & & HBV DNA - & 46 & 13 & 6 & 18 & 83 \\
\hline & & Total & 730 & 305 & 317 & 247 & 1599 \\
\hline
\end{tabular}

$\mathrm{N}$ : Normal level, H: High level 
Table 1. Prevalence of isolated anti-HBc presence in patients who were $\mathrm{N} / \mathrm{N}$ (Negative/Negative) for HBsAg/anti-HBs, Şanlıurfa, October 2009-2010

\begin{tabular}{|c|c|c|c|c|}
\hline & \multirow{2}{*}{$\mathrm{N} / \mathrm{N}$} & \multicolumn{2}{|c|}{$\mathrm{N} / \mathrm{N}$} & \multirow{2}{*}{$\begin{array}{l}\text { Isolated anti-HBC } \\
\text { (\% of total) }\end{array}$} \\
\hline & & Anti-HBc - & Anti-HBc + & \\
\hline \multicolumn{5}{|l|}{ Sex } \\
\hline Male (N:1103) & 15 (1.4\%) & & 0 & 0 \\
\hline Female (N:559) & $11(2 \%)$ & & $2(10.0 \%)$ & $0.4 \%$ \\
\hline \multicolumn{5}{|l|}{ Age (years) } \\
\hline $0-14(\mathrm{~N}: 110)$ & 0 & 0 & 0 & 0 \\
\hline $15-40(\mathrm{~N}: 1046)$ & $16(1.4 \%)$ & $16(100 \%)$ & 0 & 0 \\
\hline $41-60(\mathrm{~N}: 444)$ & $9(2.0 \%)$ & $8(88.9 \%)$ & $1(11.1 \%)$ & $0.2 \%$ \\
\hline$\geq 61(\mathrm{~N}: 62)$ & $1(1.6 \%)$ & 0 & $1(100 \%)$ & $1.6 \%$ \\
\hline Total (N:1662) & $26(1.6 \%)$ & 24 (92.3\%) & 2 (7.7\%) & $0.1 \%$ \\
\hline
\end{tabular}

M: male, F: female, $\mathrm{P}$ : positive, $\mathrm{N}$ : negative

was consistent with other studies around the world and Turkey (12-14). A multicentric study found that average age of patients infected with Hepatitis $B$ is lower in Southeastern Anatolia region $(26.2 \pm 11.3)$ when compared to other regions (15). Toy et al investigated 339 studies about HBsAg prevelance in Turkey between the years 1999-2009, and found out that the prevelance in East and Southeast Anatolia is highest in the age group of $15-24$ years (\%12.51) (12). HBsAg positivity was highest among the ages $15-40$ in our study. High prevelance in younger age groups may be associated with factors like lower living standards, low socioeconomic status, close contact and a high rate of vertical and horizontal transmission (11), which are also the causes of higher HBV infection rates.

Studies showed that, HBV DNA could be demonstrated either in circulation or in liver tissue in every patient that $\mathrm{HBsAg}$ is detected (16). We found a very high rate of HBV DNA positivity $(94.6 \%)$ in HBsAg positive patients' blood samples in our study.

We also found HBV DNA in $7.9 \%$ of HBsAg negative patients. Similarly, even higher rates in chronic hepatitis patients, were reported in literature (17). This HBV DNA positivity in seronegative patients could be associated with mutant strains (18). These results suggest that, determining HBV replication only by detection of HBV marker is not enough and real-time PCR should be used simultaneously for more reliable results (19).

$\mathrm{HBeAg}$ positivity in $\mathrm{HBsAg}$ positive patients has reported as $8-13 \%$ in Turkey. $(15,20-22)$. In our study this rate was $17.1 \%$, which also indicates high HBV prevalence in our region.

$\mathrm{HBeAg}$ is detected during active viral replication, usually in patients with positive serum HBV DNA (4). In our study, HBV DNA was positive in $98.9 \%$ of $\mathrm{HBsAg}$ and $\mathrm{HBeAg}$ positive patients. Presence of 
HBV DNA in HBeAg positive patients was found to be $80.5 \%$ by Ozbilge et al, $81.6 \%$ by Pekbay et al and $61 \%$ by Heper et al. $(18,23,24)$. As these results suggest HBV DNA can be found negative in some HBeAg positive patients, which may be related to regional variability of mutant strains. Furthermore, it is very important to know whether the patient has been treated or not when HBV DNA and HBsAg serological tests are interpreted. It should be kept in mind that in some situations, especially when $\mathrm{HBeAg}$ is positive, HBV DNA may be negative or low positive while the patient is receiving antiviral treatment. HBV DNA could not be isolated in three $\mathrm{HBeAg}$ positive patients in present study. This condition has been reported in similar studies. $(23,25,26)$. Lack of the information about treatment states of these patients is a disadvantage of our study.

HBV DNA was positive in $98.9 \%$ of $\mathrm{HBsAg}$ and HBeAg positive patients and serum ALT levels were elevated in $61.9 \%$ of them while it was normal in $38.1 \%$. These results suggest immune tolerant phase (presence of $\mathrm{HBeAg}$, high positivity of HBV DNA and normal ALT levels) and immune clearance phases (presence of $\mathrm{HBeAg}$, high positivity of HBV DNA and elevated ALT levels), respectively. To precisely determine the phase of chronic hepatitis in patients, these findings have to be evaluated together with liver biopsy results (27). To find out the phase of the illness is especially important in prediction of prognosis and management of disease (28).

The anti-core antibody can induce anti-HBc responses without $\mathrm{T}$-cell activation. This antibody can be found in almost every patient with a previous contact with HBV, even in HBV carriers without other responses. This serological pattern is called 'anti-HBC alone', and might reflect an occult HBV infection $(\mathrm{OBI})$. Anti-HBc is not an ideal marker, the Taormina group recommended its use as a surrogate marker whenever an HBV DNA test is not available to identify potential seropositive $\mathrm{OBI}$ individuals such as in cases of blood, tissue or organ donation, or in cases of patients undergoing immunosuppressive therapy (7). Numerous studies have been performed to identify contamination from $\mathrm{HBsAg}$ negative persons, in other words HBV presence in HBsAg negative patients, and various results (between $1 / 46000$ and 1/630000) have been found in different countries (29). Studies in Turkey revealed isolated anti-HBC positivity between $0.011 \%$ and $6.4 \%$ (2931 ). The results of our study showed that $1.6 \%$ of individuals were $\mathrm{N} / \mathrm{N}$ based on routine serological tests for HBV (HBsAg/anti-HBs) and $7.7 \%$ of them were isolated anti-HBc positive individuals (2 patients, $0.1 \%$ of total subjects) and one of these was low positive for HBV DNA while other was negative. However, real prevalence of isolated anti$\mathrm{HBC}$ positivity is still not known due to different patient numbers of the studies and variations in the sensitivities of the tests that are used in these studies. Because of that, highly sensitive and specific PCR tests are very important for determination of real prevalence (32). Furthermore, it is known that, $\mathrm{HBV}$ infection rates in the study region are also an important factor in prevalence of isolated anti-HBc positivity. The geographical factors are found to be highly associated with isolated anti-HBc prevalence, there by endemic HBV infection (33). Our higher prevalence rates were probably due to lower number of HBsAg positive patients in our study group and high HBV prevalence of the region. We suggested that it was necessary, larger studies with accurate and highly sensitive techniques and histopathological examinations to determine the real prevalence of isolated anti-HBc positivity in patients. Generally, infection is considered to be ended when antigens disappear and anti-HBs and anti-HBc antibodies turn up in an individual. However, we found HBV DNA in $0.3 \%(5 / 1662)$ of patients even though antigens were negative and antibodies were positive. This situation supports the idea of positive anti-HBs do not necessarily mean recovery $(34,35)$. The cause of anti-HBs presence in HBV DNA positive patients has not clarified yet, but it may be attributed to 
insufficient neutralization of HBV or deficiency of determining the precise state of HBV infection with routine serologic tests.

When body tissue or an organ such as liver or heart is diseased or damaged, additional AST and ALT releases into the bloodstream, causing elevated levels of the enzymes. Therefore, the amount of AST and ALT in the blood is directly related to the extent of the tissue damage (36). It was found that median ALT and AST levels of HBsAg positive patients were elevated. This elevation in ALT and AST levels may show liver damage due to HBV replication. ALT and AST levels are important markers in diagnosis and management of acute Hepatitis B infection and acute fulminant hepatitis, as well as in diagnosis and follow-ups of inactive HBsAg carriers, according to the latest guidelines (37). It must be kept in mind that liver enzymes are important parameters in management of the patients in addition to molecular techniques that are frequently used lately.

Studies revealed that $\mathrm{HBeAg}$ positive patients have higher replication levels than $\mathrm{HBeAg}$ negative ones. Togo et al and Saglık et al showed higher ALT and HBV DNA levels in HBeAg positive patients similar to our study (3). ALT levels elevated in 61.2\% of $\mathrm{HBeAg}$ positive patients while this rate was only 28.1\% in HBeAg negative individuals in our study.

Serological markers and serum transaminase levels are not always adequate in evaluation of HBV infection. HBV DNA detection in serum sample is the best way in finding out the infectivity of the Hepatitis B infection, determining the necessity of antiviral treatment and effeciency of the treatment and evaluating the prognosis of the disease. As a result, quantitative HBV DNA tests should be used together with serological and biochemical test in the management of HBV infections.

\section{REFERENCES}

1. Busca $A$, Kumar $A$. Innate immune responses in hepatitis B virus (HBV) infection. Virol J, 2014; 11: 22.

2. Duman Y, Kaysadu H, Tekerekoğlu MS. Hepatit B virüs infeksiyonunun seroprevalansı. İnönü Üni Tıp Fak Derg, 2009; 16 (4): 243-45.

3. Sağlık I, Mutlu D, Ongut G, Güvenc HI, Akbaș H, Oğunc $D$, et al. Kronik hepatit B enfeksiyonu olan hastalarda $\mathrm{HBsAg}$ ve $\mathrm{HBeAg}$ değerlerinin HBV DNA ve Alanin Aminotransferaz düzeyleri ile karșılaștırılması. Viral Hepat J, 2013; 19 (3): 11922.

4. Genç Ö, Aksu E. Dumlupınar Üniversitesi Evliya Çelebi Eğitim ve Araștırma Hastanesinde hepatit B serolojik testlerinin uygunsuz kullanımı, Kütahya. Mikrobiyol Bul, 2014; 48(4): 618-27.
5. Ponde RA. The underlying mechanisms for the "isolated positivity for the hepatitis B surface antigen (HBsAg)" serological profile. Med Microbiol Immunol, 2011; 200: 13-22.

6. Biçeroğlu SU, Yazan Sertöz R, Zeytinoğlu A, Altuğlu i. Hepatit $B$ virus kantitasyonunda iki farklı gerçek zamanlı PCR testinin karșılaștırılması: COBAS AmpliPrep/COBAS TaqMan ve ARTHUS QS-RGQ KiT. Ege J Med, 2012; 51 (4): 233-7.

7. Ocana S, Casas ML, Buhigas I, Lledo JL. Diagnostic strategy for occult hepatitis B virus infection. World J Gastroenterol, 2011; 17 (12): 1553-7.

8. Gleason JA, Post GB, Fagliano JA. Associations of perfluorinated chemical serum concentration sand biomarkers of liver function and uricacid in the US population (NHANES), 2007-2010. Environ Res, 2015; 136: 8-14. 
9. Chen CJ, Yang HI, Su J, Jen CL, You SL, Lu SN. Risk of hepatocellular carcinoma across a biological gradient of serum hepatitis B virus DNA level. JAMA, 2006; 295: 65-73.

10. Pawlotsky JM, Dusheiko G, Hatzakis A, Lau D, Lau $\mathrm{G}$, Liang TJ, et al. Virologic monitoring of hepatitis $B$ virus therapy in clinical trials and practice: Recommendations for a standardized approach. Gastroenterology, 2008; 134: 405-15.

11. Kangin $M$, Turhanoglu $M$, Gulsun S, Cakabay B. Seroprevalence of hepatitis B and C among children in endemic areas of Turkey. Hepat Mon, 2010; 10 (1): 36-41.

12. Toy M, Önder FO, Wörmann T, Bozdayi AM, Schalm SW, Borsboom GJ, et al. Age- and region-specific hepatitis B prevalence in Turkey estimated using generalized linear mixed models: a systematic review. BMC Infect Dis, 2011; 12: 337.

13. Sünbül $M$, Leblebicioğlu $H$. Distribution of hepatitis $B$ virus genotypes in patients with chronic hepatitis B in Turkey. World J Gastroenterol, 2005; 11: 197680.

14. Sagnelli E, Stroffolini T, Ascione A, Chiaramonte M, Craxì A, Giusti G, et al. Decrease in HDV endemicity in Italy. J Hepatol, 1997; 26: 20-4.

15. Celen MK, Koruk ST, Aygen B, Dal T, Karabay O, Tosun S, Koksal I, Turgut H, Onlen Y, Balik I, Yildirim N, Dal MS, Ayaz C, Tabak F. The characteristics of patients with chronic hepatitis B in Turkey. Med Glas (Zenica), 2014; 11(1):94-98.

16. Kangin $M$, Turhanoglu $M$, Gulsun $S$, Cakabay B. Seroprevalence of Hepatitis B and C among Children in Endemic Areas of Turkey. Hepatitis Monthly, 2010; 10(1):36-41.

17. Ergünay K. Gizli (okült) hepatit B enfeksiyonu. Mikrobiyol Bul, 2005; 39:241-249.

18. Altındiș $M$. Hepatit $B$ virus (HBV) serolojik belirtecleri ile HBV DNA'nın varlığının karșılaștırılması. İnfeksiyon Dergisi (Turkish Journal of Infection), 2002; 16 (2): 141-5.

19. Özbilge H, Zeyrek FY, Mızraklı Uzala A, Tümkaya B. Hepatit $B$ virus DNA pozitifliği ve serolojik testler. Erciyes Tıp Dergisi (Erciyes Medical Journal), 2005; 27 (1)17-21.
20. Ghafourian S, Mohebi R, Khosravi A, Maleki A, Davoodian A, Sadeghifard N. Detection of Hepatitis B Virus DNA by Real-Time PCR in Chronic Hepatitis B Patients, Ilam, Iran. Middle-East Journal of Scientific Research, 2011; 9 (4):478-480.

21. Kaya Ş, Baysal B, Temiz H, Karadağ Ö, Özdemir $\mathrm{K}$, Bilman F. Seroprevalence of hepatitis B and C among patients admitted to a tertiary hospital. Viral Hepat J, 2014; 20: 120-4.

22. Demirturk N, Demirdal T, Toprak D, Altindis $M$, Aktepe OC. Hepatitis B and C virus in West-Central Turkey: seroprevalence in healthy individuals admitted to a university hospital for routine health checks. Turk J Gastroenterol, 2006; 17 (4): 267-72.

23. Pekbay A, Günaydın M, Eroğlu C, Bedir A, Esen Ş, Leblebicioğlu H. Hepatit B virüsü (HBV) serolojik göstergeleri ile HBV DNA arasındaki korelasyon. Viral Hepat Derg, 2001; 2: 302-4.

24. Heper Y, Mıstık R, Özakın C, Töre O. Hepatit B virus (HBV) markerleri ile HBV- DNA ilișkisi: Bursa bölgesi sonuçları. Viral Hepat Derg, 1999; 2: 137-9.

25. Yücesoy $M$, Bahar îH, Yuluğ N. Hepatit $B$ virüs (HBV) serolojik belirleyicileri ile HBV DNA'nın karșılaștırılması. İnfeksiyon Derg, 1999; 4: 581-4.

26. Külah C, Cömert F, Özlü N, Eroğlu Ö , Tekin iö. Hepatit B Virus (HBV) Infeksiyonunda serolojik belirteçler, transaminaz düzeyleri ve HBV DNA'nın birlikte değerlendirilmesi. Viral Hepat Derg, 2007; 12 (3): $111-5$

27. Hadziyannis SJ. New developments in the treatment of chronic hepatitis B. Expert Opin. Biol. Ther, 2006; 6 (9): 913-21.

28. Değertekin $H$, Oğuz AK. Akut ve kronik HBV infeksiyonunda doğal seyir. Güncel Gastroenteroloji, 2010; 14/2: 54-8.

29. Bal SH, Heper Y, Kumaș LT, Mıstık R, Töre O. İzole Anti-HBC pozitif olgularda HBV-DNA varlığının araștırılması ve bu olguların kan bankacılığı açısından önemi. Mikrobiyol Bul, 2009; 43: 243-50.

30. Altunay H, Kosan E, Birinci I, Aksoy A, Kirali K, Saribas S, et al. Are isolated anti-HBC blood donors in high risk group? The detection of HBV DNA in isolated anti-HBC cases with nucleic acid amplification test (NAT) based on transcriptionmediated amplification (TMA) and HBV discrimination. Transfus Apher Sci, 2010; 43: 265-8. 
31. Yakaryilmaz F, Gurbuz OA, Guliter S, Mert A, Songur $\mathrm{Y}$, Karakan T, et al. Prevalence of occult hepatitis $B$ and hepatitis C virus infections in Turkish hemodialysis patients. Ren Fail, 2006; 28: 729-35

32. Cabrerrizo M, Bartolome J, Caramelo C, Barril G, Carreno V. Molecular analysis of hepatitis B virus DNA in serum and peripheral blood mononuclear cells from hepatitis B surface antigen-negative cases. Hepatology, 2000; 32: 116-23.

33. Utsumi T, Yano Y, Truong B, Kawabata M, Hayashi Y. Characteristics of occult hepatitis B virus infection in the Solomon Islands. Int J Mol Med, 2011; 27: 829-34.

34. Tanaka $Y$, Esumi M, Shikata T. Persistence of hepatitis $B$ virus DNA after serological clearance of hepatitis B virus. Liver, 1990; 10: 6-10.
35. Fukuda R, Ishimura N, Niigaki M, Hamamoto S, Satoh $S$, Tanaka S, et al. Serologically silent heapatitis $B$ virus coinfection in patients with hepatitis C virus-associated chronic liver diseases:clinical and virological significance. J Med Virol, 1999; 58: 2017.

36. Huang XJ, Choi YK, Im HS, Yarimaga O, Yoon E, Kim HS. Aspartate aminotransferase (AST/GOT) and alanine aminotransferase (ALT/GPT) detection techniques. Sensors, 2006; 6: 756-82.

37. III. Viral hepatit tanı ve tedavi rehberi. Viral hepatitle savaşım derneği. Ankara, 2011. 